\title{
The Date Palm (Phoenix dactylifera L.): Overview of Biology, Uses, and Cultivation
}

\author{
ChihCheng T. Chao ${ }^{1}$ \\ Department of Botany and Plant Sciences, University of California-Riverside, Riverside, CA 92521-0124
}

Robert R. Krueger ${ }^{2}$

United States Department of Agriculture-Agricultural Research Service, National Clonal Germplasm Repository for Citrus and Dates, 1060 Martin Luther King Boulevard, Riverside, CA 92507-5437

Additional index words. genetic relationships, Khalal, Kimri, Rutab, Tamar, offshoot, off type, pollination, tissue culture, metaxenia

\begin{abstract}
Date palm (Phoenix dactylifera L.) is one of the oldest fruit crops grown in the arid regions of the Arabian Peninsula, North Africa, and the Middle East. The most probable area of origin of the date palm was in or near what is now the country of Iraq, but date cultivation spread to many countries starting in ancient times. Dates are a major food source and income source for local populations in the Middle East and North Africa, and play significant roles in the economy, society, and environment in these areas. In addition to serving directly as a food source, dates are packed and processed in a number of ways, and other parts of the tree are used for various purposes. The date palm is a diploid, perennial, dioecious, and monocotyledonous plant adapted to arid environments. It has unique biological and developmental characteristics that necessitate special propagation, culture, and management techniques. Thousands of date palm cultivars and selections exist in different date-growing countries. Different genetic marker systems have been used to study genetic relationships among date palm cultivars. The long life cycle, long period of juvenility, and dioecism of date palms make breeding challenging. Worldwide date production has grown from $1,809,091 \mathrm{t}$ in 1962 to $6,924,975 \mathrm{t}$ in 2005 . Worldwide date production will continue to grow, especially in the Middle East, despite current and future challenges.
\end{abstract}

\section{HISTORY OF DATE PALMS}

Date palm (Phoenix dactylifera L.) has long been one of the most important fruit crops in the arid regions of the Arabian Peninsula, North Africa, and the Middle East. During the past three centuries, dates were also introduced to new production areas in Australia, India/Pakistan, Mexico, southern Africa, South America, and the United States. Dates are a main income source and staple food for local populations in many countries in which they are cultivated, and have played significant roles in the economy, society, and environment of those countries.

Date is one of the oldest known fruit crops and has been cultivated in North Africa and the Middle East for at least 5000 years (Zohary and Hopf, 2000). The earliest record from Iraq (Mesopotamia) shows that date culture was probably established as early as 3000 BCE. Because of the long history of date culture and the wide distribution and exchange of date cultivars, the exact origin of the date is unknown, but it most likely originated from the ancient Mesopotamia area (southern Iraq) or western India (Wrigley, 1995). From its center of origin, date cultivation spread through out the Arabian Peninsula, North Africa, and the Middle East. Date culture had apparently spread into Egypt by the middle of the second millennium BCE. The spread of date cultivation later accompanied the expansion of Islam and reached southern Spain and Pakistan. The Spanish were the first to introduce date palms outside the Arabian Peninsula, North Africa, and the Middle East/South Asia, carrying them to America (Nixon, 1951).

\footnotetext{
${ }^{1}$ Current address: Thermal Plaza Nursery, 8035-P Highway 86, Thermal, CA 92274.

2E-mail rkrueger@ucr.edu.
}

Date cultivation has had a very important influence on the history of the Middle East. Without dates, no large human population could have been supported in the desert regions. The caravan routes existed for centuries mainly for the transportation of dates. Early on, date cultivation became a sacred symbol of fecundity and fertility. Dates had great spiritual and cultural significance to the people of the Middle East. Date palms and culture are depicted in ancient Assyrian and Babylonian tablets, including the famous Code of Hammurabi, which contained laws pertaining to date culture and sales. References relating to date palms are also found in ancient Egyptian, Syrian, Libyan, and Palestinian writings (Nixon, 1951; Popenoe, 1973).

\section{WORLDWIDE PRODUCTION OF DATE PALMS}

Dates can grow in very hot and dry climates, and are relatively tolerant of salty and alkaline soils. Date palms require a long, intensely hot summer with little rain and very low humidity during the period from pollination to harvest, but with abundant underground water near the surface or irrigation. One old saying describes the date palm as growing with "its feet in the water and its head in the fire." Such conditions are found in the oases and wadis of the date palm's center of origin in the Middle East (Fig. 1). Date palms can grow from 12.7 to $27.5^{\circ} \mathrm{C}$ average temperature, withstanding up to $50^{\circ} \mathrm{C}$ and sustaining short periods of frost at temperatures as low as $-5^{\circ} \mathrm{C}$. The ideal temperature for the growth of the date palm, during the period from pollination to fruit ripening, ranges from 21 to $27{ }^{\circ} \mathrm{C}$ average temperature. Dates are widely grown in the arid regions between $15^{\circ} \mathrm{N}$ and $35^{\circ} \mathrm{N}$, from Morocco in the west to India in the east (Zaid and de Wet, 2002a).
Worldwide date production has increased from $1,809,091 \mathrm{t}$ in 1962 to $6,924,975 \mathrm{t}$ in 2005 (Food and Agriculture Organization of the United Nations, 2006). The top 10 dateproducing countries in 2005 were Egypt, Saudi Arabia, Iran, United Arab Emirates (UAE), Pakistan, Algeria, Sudan, Oman, Libyan Arab Jamahiriya, and Tunisia. The top five date-exporting countries in 2004 were Iran, Pakistan, UAE, Saudi Arabia, and Tunisia. The top five date-importing countries in 2004 were India, Pakistan, Yemen, Morocco, and UAE. The United States (California and Arizona) produced 16,500 t of date in 2005 and exported $4202 \mathrm{t}$ (ranked 10 th worldwide). The United States also imported $5584 \mathrm{t}$ of date in 2004. As with many fruits produced in California, date quality is high and commands a price advantage for exports. The relatively large volume of imported dates is most probably in the form of processed products.

The largest production of dates is in Egypt, where production has increased from $439,539 \mathrm{t}$ in 1982 to $1,170,000 \mathrm{t}$ in 2005 ( $16.9 \%$ of worldwide production). In UAE, there were about 1.5 million date palms producing $8400 \mathrm{t}$ when the country was founded in 1971. This has increased more than 90 -fold to an estimated 18 millions date palms producing 760,000 $\mathrm{t}$ in 2005. Currently, UAE has the largest date tissue culture (TC) facility, where more than 100,000 TC date palms are produced annually, because offshoot production cannot keep up with the demand for new trees to plant (Date Palm Tissue Culture Laboratory, 2006).

\section{REPRODUCTIVE BIOLOGY OF DATE PALMS}

Date palm is a diploid $(2 \mathrm{n}=2 \mathrm{x}=36)$, perennial, and monocotyledonous plant 


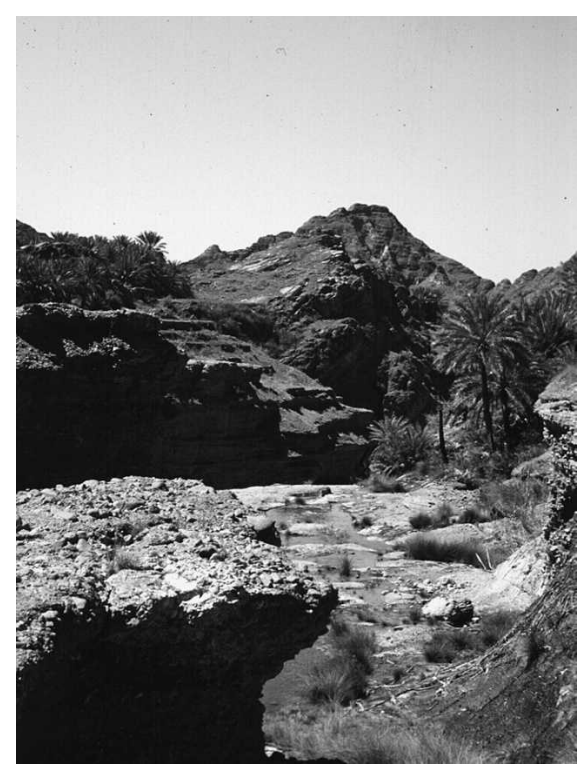

Fig. 1. The Khattwa Oasis in Oman is representative of the types of conditions in which date palms originated and are adapted. Traditional date palm cultivation is still practiced in such oases. (R.R. Krueger)

belonging to Palmaceae (Barrow, 1998). The name of date palm originates from its fruit; "phoenix" from the Greek means purple or red (fruit), and "dactylifera" refers to the finger-like appearance of the fruit bunch. Date palm is dioecious, meaning it has separate female and male trees. Throughout the years, there have been various reports of hermaphroditic trees developing, or male trees developing female characteristics (Sudhersan and Abo El-Nil, 1999). Inflorescences of female and male trees differ in morphology (Nixon and Carpenter, 1978; Swingle, 1904; Vandercook et al., 1980). Both are enclosed in a hard, fibrous cover (the spathe) that protects the flowers from heat and sunlight during the early stage of flower development.

Dates flower when the shade temperature increases to more than $18{ }^{\circ} \mathrm{C}$, and form fruit when it is more than $25^{\circ} \mathrm{C}$ (Zaid and de Wet, 2002a). The flowers (and later the fruit on female trees) are borne on a flat, tapering peduncle or rachis, commonly known as the "fruit stalk" in the female trees. The inflorescence consists of many unbranched rachillae, known as "strands," arranged in spirals on the rachis. Both female and male flowers usually have three sepals and three petals (Fig. 2). Male flowers are usually waxy white and female flowers usually are yellowish green. Just before flowering, the inflorescence arises in the axis of the leaves, pushing through the sheaths, and the sheaths crack longitudinally at anthesis. Only the portion of the rachilla that bears flowers is exposed. Fifty to $60 \mathrm{~d}$ after anthesis, the fruit stalk elongates and pushes out the portion of the inflorescence that does not bear flowers to a length of 60 to $120 \mathrm{~cm}$. The fruit normally develops after fertilization from one of the three carpels within each pistillate flower.

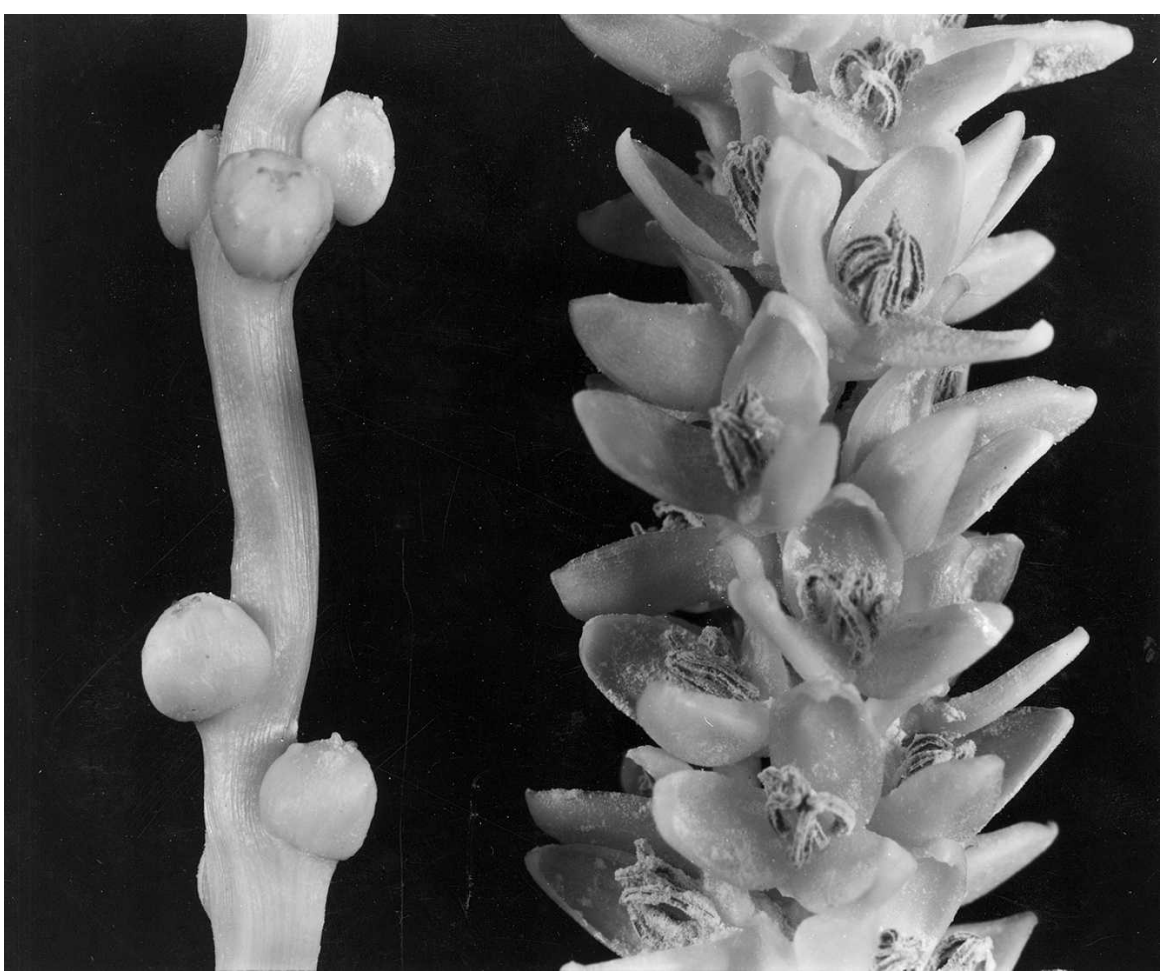

Fig. 2. Male (left) and female (right) flowers of date palm. (USDA archival photograph)

Natural fruit drop occurs 25 to $35 \mathrm{~d}$ after spathe cracking, and some cultivars have a second fruit drop about $100 \mathrm{~d}$ after spathe cracking (sometimes referred to as "June drop") (Reuveni, 1986).

The growth rate and development of seeded fruit follow a sigmoid growth curve. The date fruit goes through four distinct ripening stages. These four stages are usually referred to in terms derived from Iraqi Arabic as "Kimri," "Khalal" (sometimes referred to as "Bisr"), "Rutab," and "Tamar" to represent the immature green, the mature full colored, the soft brown, and the hard raisinlike stages respectively (Reuveni, 1986). During the Kimri stage, the fruit increase in size and weight rapidly until the Khalal stage. The fruit color changes from green during Kimri to a color characteristic of the cultivar during Khalal. The fruit remain turgid and astringent during Khalal, and contain a substantial amount of water-soluble tannins. During the Khalal stage, the rate of gain in size and weight decreases slightly and the fruit reach full size and weight. Fruit during the Rutab stage are characterized by a darkening of the skin to amber, brown, or nearly black, accompanied by softening, decreasing astringency, and increasing insoluble tannins. During the Tamar stage, fruit lose much of their water and the sugar-to-water ratio is high enough to prevent fermentation, similar to raisins or dried prunes. Water content is $75 \%$ to $80 \%$ in young fruit, decreasing to $40 \%$ to $60 \%$ at the beginning of ripening, and decreasing rapidly later. The sugar content is about $20 \%$ dry matter during early Kimri, increasing steadily to $50 \%$ dry matter at the beginning of Khalal, and then accumulating at a faster rate until reaching $72 \%$ to $88 \%$ of dry matter at maturation (Reuveni, 1986). Date fruit vary in size and shape depending on cultivar, culture, and environment. The average date palm produces $40 \mathrm{~kg}$ fruit annually, with yields of more than $100 \mathrm{~kg}$ possible with intensive management. When farmed with low levels of inputs and management, dates may produce $20 \mathrm{~kg}$ fruit or less annually. Female plants start producing dates at 4 to 6 years of age and reach full production within 15 to 20 years (Nixon and Carpenter, 1978).

\section{CULTIVATION OF DATE PALMS}

The average economic life of a date garden is 40 to 50 years, but some are still productive up to 150 years. There are a few date palms that are probably several hundred years old. Because of the biology of the date palm, its cultivation has a number of unusual features that are not common in other perennial crops. There are a number of cultural practices that require access to the crown of the tree, and in old trees reaching tens of meters in height, this can be challenging and sometimes dangerous. The crown of the tree needs to be accessed for pollination, bunch tie-down, covering, harvesting, and pruning. Although the practice of climbing the trees for access to the crown in still found in all date-producing areas, the use of mechanical lifts is common in more advanced or industrialized production areas, such as the United States (Nixon and Carpenter, 1978).

Date is wind pollinated in nature, but insect pollination is possible. Commercially, few male trees are grown in date gardens, and 
pollen is collected for the artificial pollination that is critical for the success of production. Artificial pollination has been practiced in North Africa and the Middle East for thousands of years. Pollination of $60 \%$ to $80 \%$ of the female flowers results in adequate fruit set. Cultivars differ greatly in their fruit set percentage. Incompatibility or partial incompatibility between different female and male cultivars is common but not well understood. Only one ovule per flower is fertilized, producing a single fruit (Nixon and Carpenter, 1978; Zaid and de Wet, 2002c).

Different pollen sources can influence the size and shape of the seeds ("xenia" effect). Pollen also can have a "metaxenia" effect, influencing the tissue outside the embryo and endosperm (Nixon, 1934, 1936; Reuveni, 1986). As an example of metaxenic effects in date palms, Nixon (1934) reported that 'Fard No. 4' consistently produced earlier but smaller fruit than the average of all pollen sources studied, whereas 'Mosque' consistently produced larger but later fruit than the average. Pollination with pollen from different Phoenix species also exhibited metaxenic effects (Nixon, 1936). Although similar effects have been reported from various other countries, in some cases no observable effects were reported from pollinations with pollen from different males tested. This has been attributed to the fact that metaxenic effects are less pronounced when climatic conditions are favorable (i.e., higher heat units) or the possibility that the specific males tested did not produce metaxenic effects (Reuveni, 1986).

After pollination, bunches are often tied to the leaf stalks to support the weight of the fruit. Fruit thinning is sometimes practiced in date cultivation. Fruit thinning is used to decrease alternate bearing, increase fruit size, improve fruit quality, advance fruit ripening, and facilitate bunch management. Fruit thinning can be carried out three ways: removal of entire bunches, reduction in the number of strands per bunch, and reduction in the number of fruit per strand. Cultivar, climate, and cultural practices influence the appropriate levels of fruit thinning. Bunches of dates are usually covered (bagged) in the United States with brown craft paper, white paper, or cotton or nylon mesh bags. Bagging can protect fruit bunches from high humidity and rain, minimize damage from sunburn, and decrease losses from birds (Nixon and Carpenter, 1978; Zaid and de Wet, 2002c).

Although dates palms can withstand long periods of drought under high temperatures, large amounts of water are required for vigorous growth, high yield, and high-quality fruit. Under typical production conditions in California, annual water consumption was $\approx 1.3 \mathrm{~m}$ (Furr and Armstrong, 1956). The majority of this was from the upper $2 \mathrm{~m}$ of the soil, which coincided with the distribution of the roots. It should be noted that this study was conducted with 'Khadrawy', a smallstature cultivar that most probably would have lower water consumption than larger size cultivars. Under similar conditions, application of excess water did not increase the rate of growth of date palms or fruit yield; however, withholding water during the summer months decreased the rate of tree growth and decreased the moisture content of the fruit (Reuther and Crawford, 1945). Flood irrigation is the oldest form of irrigation and is still used in many areas. Sprinkler, micro sprinkler, and drip irrigation are often used in newer plantations (Abdul-Baki et al., 2002).

Date palms are usually fertilized, although in many cases only with nitrogen (Nixon and Carpenter, 1978). Responses to fertilization are inconsistent and probably depend upon cultivar, soil type, and other factors. For instance, in the United States, Furr and Cook (1952) sampled 'Deglet Noor' and 'Khadrawy' and reported that $\mathrm{N}$ concentrations were higher in leaves of fertilized trees compared with nonfertilized trees. However, there was not a consistent correlation with yield either of fertilization or of leaf $\mathrm{N}$ levels. There was an apparent weak response from 'Deglet Noor', but none was observed with 'Khadrawy'. Labanauskas and Nixon (1962) sampled healthy and declining palms but noted no significant differences in nutrient concentrations. The values reported for most elements were lower than those established for citrus. Date palm leaf nutrient concentrations published from various countries are inconsistent but generally have shown low $\mathrm{N}$ concentrations compared with other perennial crops. Interestingly, concentrations from date palms grown in the United States and receiving high levels of $\mathrm{N}$ have consistently been lower than those reported for date palms in the Middle East and North Africa (Krueger, in press).

Manure has traditionally been used in date production, but in many instances inorganic fertilizers are used. Many producers, even in industrialized production, consider manure to be superior to inorganic fertilizer. Cover crops are also often used in date production (Abdul-Baki et al., 2002). In arid regions, date palms can provide shade for growing other crops. Intercropping of dates with fruits, vegetables, and pasture is common in traditional areas of date production.

There are three methods for date palm propagation (Nixon and Carpenter, 1978; Zaid and de Wet, 2002b). The most common method is the vegetative propagation of offshoots, which ensures the genetic identity of maternal varieties (Fig. 3). Offshoots develop from axillary buds on the trunk near the soil surface during the date palm's juvenile stage. Offshoots, after 3 to 5 years of attachment to the parental palm, produce roots and can be removed and planted. This is about the age that the offshoots will begin to produce flowers and, in female lines, fruit. The second propagation method is to use chance seedlings from sexual crosses. Seedlings are not identical to the maternal trees and not uniform genetically, varying greatly in their production and fruit quality. About $50 \%$ of the seedlings are male although they cannot be identified until trees began to flower after $\approx 4$ to 5 years. Production and fruit quality from seedling-derived groves are greatly reduced compared with groves developed from offshoots.

The third date propagation method is through TC (Zaid and de Wet, 2002b). Tissue culture propagation of date palms from shoot tips through either embryogenesis or organogenesis was first developed in the 1970 to 1980s. Organogenesis can be achieved using auxiliary buds and apical meristems, whereas embryogenesis can be done through callus stage from various meristematic tissues like shoots, young leaves, stem, rachilla, and so forth. Cultivars respond to TC differently, and different optimal conditions are needed for each cultivar. It takes about 6 years to reach production through the TC process and 8 years to reach commercial quantities. In general, TC progenies have similar characteristics as those derived from offshoot propagation. However, one of the main problems with TC propagation is somaclonal variation (off types). These somaclonal variants exhibit several typical phenotypes, including variegation in leaves, variation in leaf structure and overall plant growth patterns, trees that do not form inflorescences or produce abnormal floral development, and trees that produce seedless parthenocarpic fruits. Most somaclonal variants can be detected in the early stages; however, some can only be detected in the field, several years after planting or after flowering, fruit set, and maturation of the trees. The frequency of somaclonal variation in TC-derived date palms can be very high sometimes, but mechanisms causing these variations are unclear and are under investigation (Gurevich et al., 2005).

\section{PESTS AND DISEASES OF DATE PALMS}

Date palms are afflicted with many diseases and pests, but the nature and severity of the problems vary with cultivar, location, weather, and cultural practices (Carpenter and Elmer, 1978; Zaid et al., 2002). Most reported diseases of date palm that can be associated with a pathogen are attributed to fungi. However, there are several recent reports of phytoplasma-associated disorders. One of the most serious fungal diseases in North Africa is the Bayoud disease incited by Fusarium oxysporum f. sp. albedinis. This disease has caused large losses of date palms, and research concerning Bayoud is one of the most important areas of date palm research. Various insects attack date palms, but specific insect problems vary with geographic area. Chemicals, biological control, pheromone trapping, quarantine, and sanitation practices are used to control insect pests of date palms (Howard et al., 2001). An emerging pest of date palm during the past decade is the red palm weevil, which has spread from India to North Africa, the Middle East, and southern Europe. Weed control is usually achieved by herbicide application or, in less developed areas, by hand weeding. 


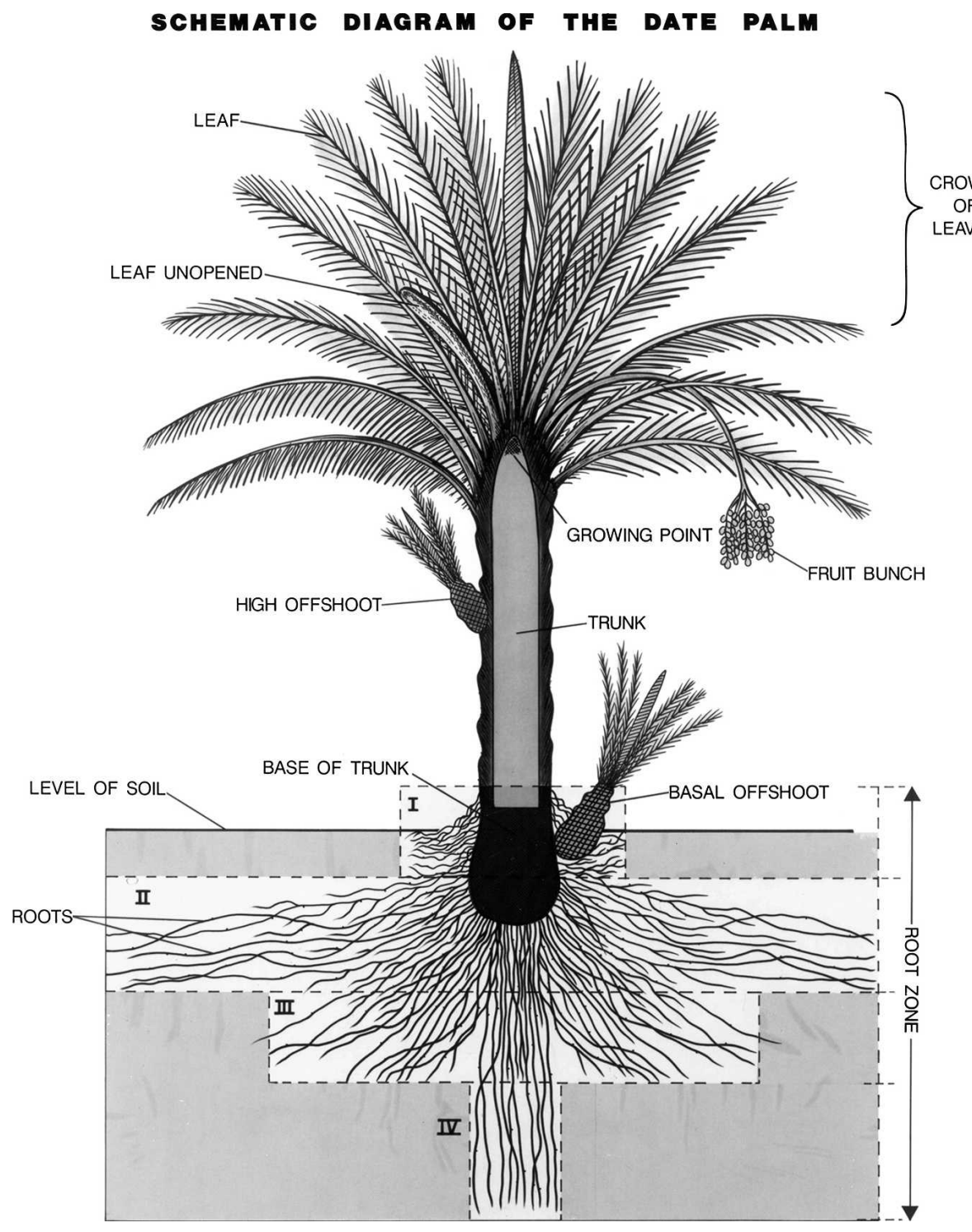

Fig. 3. Diagrammatic representation of date palm structure, showing attachment of offshoot to mother palm, among other morphological features. (USDA archival diagram)

In addition to pests and diseases, various other factors may negatively affect date palm production. Carpenter (1981) discussed problems in traditional date cultivation including crowding of trees, retention of old or unproductive trees, planting of mixed cultivars or seedlings, salt accumulation, poor drainage, insufficient irrigation, fertilization or tillage, lack of insect and disease control, competition with other crops, soil degradation, and water scarcity. Jaradat (2001) considered drought, high salinity, aged trees, Bayoud disease, and genetic erosion as the major constrains for future date palm production worldwide.

\section{HARVEST AND POSTHARVEST HANDLING OF DATES}

Dates are harvested at or near maturity. Harvest is generally by hand, with access to the crown of the tree being by way of climbing or mechanical lifts. Completely mechanized harvest by shakers, such as those chemicals, controlled atmospheres, and physical control methods (Glasner et al., 2002). Fruit quality may be manipulated through hydration, dehydration, or curing as appropriate, and dates are generally stored under refrigerated conditions in industrial produc-

OF tion (Glasner et al., 2002; Rygg, 1975).

LEAVES Sorting and grading of dates is generally performed by hand rather than by electronic devices at this time.

Fruit quality of dates can be lowered by physiological and pathological factors (Rygg, 1975). Physiological defects include blacknose, associated with high humidity during the Khalal stage; black scald, associated with abnormally high temperatures; and puffiness of the dates associated with high temperature and humidity. Storage conditions may also promote fruit defects such as darkening of the skin and sugar spots. In addition, dates are sometimes attacked by various pathogens including Aspergillus, Alternaria, and Penicillium.

\section{USES OF DATES AND DATE PALMS}

Date palms produce many products that are useful to humans. The primary product is the date fruit, which can be eaten fresh, dried, or in various processed forms. In North Africa and the Middle East, some dates are harvested and consumed during the Khalal stage, when the fruit are still very astringent with a high tannin content (Dowson and Aten, 1962; Glasner et al., 2002; Kader, 1992). However, most dates are harvested during the fully ripened Rutab and Tamar stages, when they are high in sugar and low in moisture and tannin. Cultivars of dates can be classified into "soft," "semidry," or "dry" dates, depending upon the time of harvest and associated water content. Some cultivars are used in more than one manner. Fruit quality is influenced by size, color, texture, cleanliness, freedom from defects (sunburn, insect damage, sugar migration to surface, fermentation), and the effects of decay-causing pathogens. Date fruit are available in different forms, including whole pitted and unpitted, dehydrated pieces, diced, extruded date pieces, and macerated fruit. Dates can be used in cereal, pudding, bread, pressed cakes, cookies, candy bars, ice cream, and date shakes (a California specialty). Date fruit also can be made into juice, vinegar, wine, beer, sugar, syrup, honey, chutney, pickle, paste, dip, and food flavoring (Barreveld, 1993; Glasner et al., 2002).

Date fruit are high-energy food sources with $72 \%$ to $88 \%$ sugar content at maturity. During the Khalal stage, nearly all $(80 \%$ to $85 \%$ ) of the sugar is sucrose. As ripening progresses, the sucrose is hydrolyzed into reduced sugars such as glucose and fructose. Date fruit are good sources of iron and potassium; a fair source of calcium, chlorine, copper, magnesium, and sulfur; and a minor source of phosphorus. In addition, dates are a source of 16 amino acids and vitamins A, $\mathrm{B}_{1}$, and $\mathrm{B}_{2}$ (Ahmed et al., 1995; Vandercook et al., 1980). 
As a result of the long history of cultivation and utilization of date palms, almost every part of the date palm can be used for some purpose (Barreveld, 1993; Dowson and Aten, 1962; Nixon, 1951). It is said that there are as many uses of dates as there are days in a year. The trunk and wood of date palms can be used as timber, wood, or fuel. Fiber from the trunk and leaves can be made into bags, baskets, camel saddles, cords, crates, fans, food covers, furniture, mats, paper, ropes, trays, and twine. Dried bundles of leaves ("Barusti") can be made into shades, roofs, separating walls, and enclosures. Ribs of the leaves can be used to build boats (small fishing boats called "Shasha") or fishing traps. The base of the leaves and fruit stalks can be used for fuel. The pith of the palms can be made into date palm flour. Terminal buds (palm heart) can be eaten as a salad or as a cooked vegetable. Date seeds can be used as feed for livestock or strung as beads for decoration. Oil from date seeds can be manufactured into soap. Date fruit also have many medicinal uses. They can be used as an astringent for treating intestinal problems; treatment for sore throat and colds; relief of fever, cystitis, edema, liver, and abdominal problems; to counteract hangovers; and many more uses. In India, the gum or exudate of dates is used for treating diarrhea and the roots are used to treat toothache.

Groves of date palms are important environmental niches for local wildlife and play a central role in the desert ecological system. Date palms have been effective for the control of desertification and land reclamation in the Arabian Peninsula, especially in UAE. Feral date trees in southern Australia are sometimes considered invasive species (Gotch et al., 2006). In recent decades, date palms also have been used for ornamental and landscape purposes in southern Europe and the United States (Arizona, California, Nevada, and Florida).

\section{CULTIVARS AND GENETICS OF DATE PALMS}

Nomenclature of date cultivars is confusing because of the long history of cultivation, wide exchanges of germplasm, dioecism, and seedling propagation. Thousands of named date cultivars exist in the Arabian Peninsula, North Africa, and the Middle East, but the exact numbers are unknown. For many cultivars, large numbers of synonyms and homonyms exist between and within countries. The transliteration of Arabic names into other languages further complicates the issue, and there are usually several transliterations of a single Arabic name.

Although there are many cultivars of dates, some have become preeminent in the world market (Krueger, 2001; Nixon, 1950). 'Deglet Noor', meaning "date of the light" in Arabic, comes from the Algerian Sahara and is one of the leading cultivars grown in North Africa and California. 'Medjool', believed to have originated in the Tafilalt region of Morocco, produces large fruit widely accepted by markets around the world. 'Barhee' is a soft date with high quality from Iraq, and is often consumed during the Khalal stage. 'Halawy', meaning sweet in Arabic, is a soft, high-quality date with rich flavor from Iraq. 'Hayany' is a large, early-ripening date from southern Egypt. 'Khadrawy', meaning green in Arabic, is a short and moderately productive tree with soft fruit from southern Iraq. 'Zahidi' is a tree with a compact crown and semidry fruit from northern Iraq. There are many other local cultivars from various areas that may become more important in the future. However, 'Medjool' and 'Barhee' have become the most important cultivars produced via TC. As the production areas in the Middle East and other regions become planted with TC-derived 'Medjool' and 'Barhee', these cultivars will become even more important (Zaid and de Wet, 2002b).

The long life cycle, long juvenility, and dioecism of date palms make breeding challenging. A breeding program spanning more than 30 years was initiated by the U.S. Department of Agriculture Date and Citrus Station at Indio, CA, in 1948 (Carpenter and Ream, 1976). One of the goals of this program was to develop male cultivars derived from successive backcrosses for use in breeding programs. A number of male backcrosses were produced that had morphological similarities to the named female cultivars. However, no useful progenies were released because of sterility and low vigor from inbreeding depression. Some female cultivars derived from crossing these backcrosses with named females were also produced. However, these all had some undesirable characteristics and are maintained mostly for use by breeding programs.

Because of these obstacles, modern improvement programs have turned to biotechnological approaches, including the use of TC for mass production of clones, TC selection, Agrobacterium-based transformation, and identification of molecular markers for associated with desirable traits (Bouchireb and Clark, 1997; Djerbi, 1991). An important goal of these programs is the development of Bayoud-resistant cultivars or selections. Different marker systems such as morphological characters (Jaradat and Zaid, 2004), isozymes (Bennaceur et al., 1991), restriction fragment length polymorphism (Corniquel and Mercier, 1997), random amplified polymorphic DNA (Sedra et al., 1998), and amplified fragment length polymorphism (Cao and Chao, 2002; El-Assar et al., 2005) have been used to study the genetic relationships among different cultivars from different regions. Amplified fragment length polymorphism (Devanand and Chao, 2003; Gurevich et al., 2005) and methylation sensitive amplification polymorphism markers (Fang and Chao, unpublished) also have been used to study intracultivar genetic variation, or variation within offshoots and plants derived from TC. 'Medjool', for example, has been shown to exist as a landrace cultivar in Morocco (Elhoumaizi et al., 2006). Because of the market acceptance of certain cultivars such as 'Deglet Noor' and 'Medjool', the success of TC propagation of certain cultivars, population growth and development (dam construction), and desertification, wild date germplasm and large numbers of traditional cultivars in many countries are diminishing; urgent conservation efforts worldwide are needed.

\section{FUTURE OF DATE PALM INDUSTRIES WORLDWIDE}

The area of date production in the Arabian Peninsula and the Middle East has increased dramatically during the past few decades and is expected to continue to increase. The date palm is among the very few plants that can thrive in arid environments and it can provide enormous resources for nomadic tribes and local populations. Moreover, the date palm and date fruit have great cultural and traditional significance in that region and in other Islamic countries. Populations in many of these countries are increasing, and this will result in a larger demand for dates. As a result of these factors, cultivation of this ancient crop is expected to increase in the future.

\section{Literature Cited}

Abdul-Baki, A., S. Aslan, R. Linderman, S. Cobb, and A. Davis. 2002. Soil, water, and nutritional management of date orchards in the Coachella Valley and Bard. 2nd ed. California Date Commission, Indio, CA.

Ahmed, I.A., A.W.K. Ahmed, and R.K. Robinson. 1995. Chemical composition of date varieties as influenced by the stage of ripening. Food Chem. 54:305-309.

Barreveld, W.H. 1993. Date palm products. Food and Agriculture Organization of the United Nations, Agricultural Services Bulletin no. 101, Food and Agriculture Organization of the United Nations, Rome, Italy.

Barrow, S. 1998. A monograph of Phoenix L. (Palmae: Coryphoideae). Kew Bul. 53:513-575.

Bennaceur, M., C. Lanaud, M.H. Chevalier, and N. Bounaga. 1991. Genetic diversity of the date palm (Phoenix dactylifera $\mathrm{L}$.) from Algeria revealed by enzyme markers. Plant Breed. 107:56-69.

Bouchireb, N. and M.S. Clark. 1997. The application of biotechnology to date palm culture, $\mathrm{p}$. 183-195. In: K. Watanabe and E. Pehu (eds.). Plant biotechnology and plant genetic resources for sustainability and productivity. R.G. Landes Co., San Diego, CA.

Cao, B.R. and C.T. Chao. 2002. Identification of date palm cultivars in California using AFLP markers. HortScience 37:966-968.

Carpenter, J.B. 1981. Improvement of traditional date culture. Date Palm J. 1:1-16.

Carpenter, J.B. and H.S. Elmer. 1978. Pests and diseases of the date palm. United States Department of Agriculture, Agriculture Handbook no. 527. United States Department of Agriculture, Washington DC.

Carpenter, J.B. and C.L. Ream. 1976. Date palm breeding: A review. Date Growers Inst. Rep. 53:25-33.

Corniquel, B. and L. Mercier. 1997. Identification of date palm (Phoenix dactylifera $\mathrm{L}$.) cultivars by RFLP: Partial characterization of a cDNA probe that contains a sequence encoding a zinc finger motif. Int. J. Plant Sci. 158:152-156. 
Date Palm Tissue Culture Laboratory. 2006. Date Palm Tissue Culture Laboratory. 4 June 2007. <http://datepalm.uaeu.ac.ae/subpages/ Laboratory.html $>$.

Devanand, P.S. and C.T. Chao. 2003. Genetic variation within 'Medjool' and 'Deglet Noor' date (Phoenix dactylifera L.) cultivars in California detected by fluorescent-AFLP markers. J. Hort. Sci. Biotechnol. 78:405-409.

Djerbi, M. 1991. Biotechnologie du palmier dattier (Phoenix dactylifera L.): Voies de propagation des clones résistants au bayoud et de haute qualité dattière. Options Méditerranéennes 14:31-38.

Dowson, V.H.W. and A. Aten. 1962. Dates: Handling, processing, and packing. FAO Plant Production and Protection Series no. 13. Food and Agriculture Organization Agricultural Development, Food and Agriculture Organization, Rome, Italy.

El-Assar, A.M., R.R. Krueger, P.S. Devanand, and C.T. Chao. 2005. Genetic analysis of Egyptian date (Phoenix dactylifera L.) accessions using AFLP markers. Genet. Res. Crop Evol. 52:601-607.

Elhoumaizi, M.A., P.S. Devanand, J. Fang, and C.T. Chao. 2006. Confirmation of 'Medjool' date as a landrace variety through genetic analysis of 'Medjool' accessions in Morocco. J. Amer. Soc. Hort. Sci. 131:403-407.

Food and Agriculture Organization of the United Nations. 2006. 2005 worldwide dates production statistics. 19 Mar. 2006. <http://faostat. fao.org/faostat $/$ servlet $/$ XteServlet3?Areas $=\%$ $3 \mathrm{E} 862 \&$ Items $=577 \&$ Elements $=51 \&$ Years $=$ 2004\&Format $=$ Table $\&$ Xaxis $=$ Years $\&$ Yaxis $=$ Countries $\&$ Aggregate $=\&$ Calculate $=\&$ Domain $=$ SUA\&ItemTypes=Production.Crops.Primary\& language $=\mathrm{EN}>$.

Furr, J.R. and W.W. Armstrong. 1956. The seasonal use of water by Khadrawy date palms. Date Growers Inst. Rep. 33:5-7.

Furr, J.R. and J.A. Cook. 1952. Nitrogen content of pinnae, fruit, and seed of Deglet Noor and Khadrawy date palms as related to nitrogen fertilization. Date Growers Inst. Rep. 29: 13-14.

Glasner, B., A. Botes, A. Zaid, and J. Emmens. 2002. Date harvesting, packinghouse management and marketing aspects, p. 177-208. In: A. Zaid (ed.). Date palm cultivation. Food and Agriculture Organization Plant Production and Protection paper no. 156. Food and Agriculture Organization of the United Nations, Rome, Italy.

Gotch, T., D. Noack, and G. Axford. 2006. Feral tree invasions of desert springs. Abstracts, Third International Date Palm Conference, Abu Dhabi, United Arab Emirates, 19-21
Feb., 2006, p. 40. United Arab Emirates University, Al-Ain, U.A.E.

Gurevich, V., U. Lavi, and Y. Cohen. 2005. Genetic variation in date palms propagated from offshoots and tissue culture. J. Amer. Soc. Hort. Sci. 130:46-53.

Howard, F.W., D. Moore, R.M. Giblin-Davis, and R.G. Abad. 2001. Insects on palms. CABI International, Wallingford, Oxon, UK.

Jaradat, A.A. 2001. Date palm: A tree with a taste for salt. Biosalinity News 2:5-7.

Jaradat, A.A. and A. Zaid. 2004. Quality traits of date palm fruits in a center of origin and center of diversity. Food Agr. Environ. 2:208-217.

Kader, A.A. 1992. Postharvest biology and technology: An overview, p. 15-20. In: A.A. Kader (ed.). Postharvest technology of horticultural crops. 2nd ed. Publication 3311, University of California Division of Agriculture and Natural Resources, Berkeley, CA.

Krueger, R.R. 2001. Date palm germplasm: Overview and utilization in USA, p. 2-37. In: M.A.R Al Afifi and A.A. Al-Badawy. Proceedings, First International Conference on Date Palms. United Arab Emirates University, Al Ain, U.A.E.

Krueger, R.R. 2007. Nutritional dynamics of date palm (Phoenix dactylifera L.). Acta Hort. 736:177-186.

Labanauskas, C.K. and R.W. Nixon. 1962. Concentrations of nutrients in pinnae of date palms in relation to an unexplained die-back of leaves in Coachella Valley, California. Date Growers Inst. Rep. 39:14-15.

Nixon, R.W. 1934. Metaxenia in dates. Proc Amer. Soc. Hort. Sci. 32:221-226.

Nixon, R.W. 1936. Metaxenia and interspecific pollinations in Phoenix. Proc. Amer. Soc. Hort Sci. 33:21-26.

Nixon, R.W. 1950. Imported cultivars of dates in the United States. U.S. Department of Agriculture Circular no. 834, U.S. Department of Agriculture, Washington, DC.

Nixon, R.W. 1951. The date palm: "Tree of Life" in the subtropical deserts. Econ. Bot. 5:274-301.

Nixon, R.W. and J.B. Carpenter. 1978. Growing dates in the United States. United States Department of Agriculture Bulletin no. 207, U.S. Department of Agriculture, Washington, DC.

Popenoe, O. 1973. The date palm. Field Research Projects, Miami, FL.

Reuther, W. and C.L. Crawford. 1945. Irrigation experiments with dates. Date Growers Inst. Rep. 22:11-14.

Reuveni, O. 1986. Date, p. 119-144. In: S.P. Monselise (ed.). CRC handbook of fruit set and development. CRC Press, Boca Raton, FL.

Rygg, G.L. 1975. Date development, handling, and packing in the United States. Agricultural Research Service, United States Depart- ment of Agriculture Agricultural Handbook no. 482, Agricultural Research Service, U.S. Dept. of Agriculture. Washington, DC.

Sedra, M.H., P. Lashermes, P. Trouslot, M. Combes, and S. Hamon. 1998. Identification and genetic diversity analysis of date palm (Phoenix dactylifera L.) cultivars from Morocco using RAPD markers. Euphytica 103:75-82.

Sudhersan, C. and M. Abo El-Nil. 1999. Occurrence of hermaphroditism in the male date palm. Palms 43:18-19, 48-50.

Swingle, W.T. 1904. The date palm and its cultivation in the south-western states. USDA Bureau of Plant Industry, bulletin no. 53. United States Department of Agriculture, Washington, DC.

Vandercook, C.E., S. Hasegawa, and V.P. Maier. 1980. Dates, p. 506-541. In: S. Nagy and P.E. Shaw (eds.). Tropical and subtropical fruits: Composition, properties, and uses. AVI Publishing Company, Westport, CT.

Wrigley, G. 1995. Date palm, p. 399-403. In: J. Smartt and N.W. Simmonds (eds.). Evolution of crop plants. 2nd ed. Longman Group, Essex, UK

Zaid, A. and P.F. de Wet. 2002a. Climatic requirements of date palm, p. 57-72. In: A. Zaid (ed.) Date palm cultivation. Food and Agriculture Organization Plant Production and Protection Paper no. 156. Food and Agriculture Organization of the United Nations, Rome, Italy.

Zaid, A. and P.F. de Wet. 2002b. Date palm propagation, p. 73-105. In: A. Zaid (ed.). Date palm cultivation. Food and Agriculture Organization Plant Production and Protection Paper no. 156. Food and Agriculture Organization of the United Nations, Rome, Italy.

Zaid, A. and P.F. de Wet. 2002c. Pollination and bunch management, p. 145-175. In: A. Zaid (ed.). Date palm cultivation. Food and Agriculture Organization Plant Production and Protection Paper no. 156. Food and Agriculture Organization of the United Nations, Rome, Italy.

Zaid, A., P.F. de Wet, M. Djerbi, and A. Oihabi. 2002. Diseases and pests of date palm, p. 227 281. In: A. Zaid (ed.). Date palm cultivation. Food and Agriculture Organization Plant Production and Protection Paper no. 156. Food and Agriculture Organization of the United Nations, Rome, Italy.

Zohary, D. and M. Hopf. 2000. Domestication of plants in the old world: The origin and spread of cultivated plants in West Asia, Europe, and the Nile Valley. Oxford University Press, Oxon, UK. 